\title{
Mode Exploration of Practical Ability Cultivation Mode for English Talents Based on Integration of Industry Study and Research in College
}

\author{
Lu Chunhua ${ }^{1, a}$ \\ ${ }^{1}$ Siping vocational university foreign language institute,Siping 136002 \\ ajesslu1972@aliyun.com
}

\begin{abstract}
Keywords: English education; integration of industry; study and research; practical ability
\end{abstract}
\begin{abstract}
With continuous development of the market, the source of the students and employment is increasingly becoming the core elements of the vocational colleges for existence and development. How to make the English talent of the vocational colleges improve their professional skills in the community and realize their own value, this problem should be researched. The integration of industry study and research of the English talent is proposed, it is taken as the theoretical basis, and the new practical ability mode is proposed based on industry, study and research theory. A new integration path for improving the practical ability of English talent is explored in college.
\end{abstract}

\section{Concept of integration of industry study and research}

At present, there are many formulations about the integration of industry study and research, but its connotations and meanings are not the same at all. Its relevant understandings are proposed by people from different viewpoints. Some people propose it from macro and micro. Some people propose it from the perspective of historical, economic, social and educational angles. Some people propose the concept from the perspective of function, mode, and route. Until today, it is difficult to form a unified concept. It is generally believed that the "Industry" refers not only to a particular specific industry, but also more important is the direction of social and economic development. "Study" is not teaching in the narrow sense, but run a school in a broad sense, including the school's school system, teaching contents and methods of teaching management and many other aspects. "Research" means scientific research of course, but the direction and content of research must be clear. We should focus on researching for the "production" and serving for the "production". The so-called integration of industry study and research means the production enterprises, higher faculties, and research institutes, science and technology intermediary, and the government are combined with a unified integrity. At the same time we can bring together education, scientific research, development, production, sales and service. According to the benefit-sharing and risk sharing, the complementary advantages and common development principle are taken into consideration, the production for the direction of learning is shown as the basis for development, "research" is shown as a link, and their respective advantages are played. The economic integration of technology is promoted, and then the technical innovation activities are jointly carried out. The development of scientific research - products - market is realized with a virtuous cycle, and the research organic integrity is obtained. We can see that the integration of industry study and research is a new mode of combination of market economy and the knowledge economy. It is an important part of the national innovation system.

\section{Significance of exploring the integration of industry study and research}

With the reform and openness in China, the economic development has made a big achievement attracted worldwide attention. We should clearly recognize the fact that our comprehensive national strength as is still far below the world average level. Generally speaking, there is a large gap between the overall level of science and technology with the developed countries, and mainly it is shown as follows: key technical self-sufficiency rate at the end, the number of patent of invention is small. In some areas, especially in the central and western rural areas, the technology level is still relatively backward, and the scientific quality is not high enough. The outstanding talents are relatively scarce. The technology application is staying in low level, technology and economic integration of the problem is not completely solved[1]. According to statistics, the rate of our 
scientific and technological achievements transfer into practical productive is only $10 \%$. The contribution degree of technological progress to economic growth is less than $30 \%$, significantly lower than the level of developed countries as 60\%-70\%. Our dependence on foreign technology the key investment in fixed assets accounted for about $40 \%$ of the investment in equipment, the need to import is more than $60 \%$, the dependence degree on the investment technology is more than $50 \%$ in China, while developed countries are below 30\%, but the U.S. and Japan is only about 5\%. The critical technology and core technology are depended on the condition of human, and the occurrence is very prominent. How to meet these challenges, and convert the challenges into opportunity is becoming very important. Under this condition, a new mode of cultivating the talents is important. And make the higher education, technological progress and economic development of the Chinese nation developed with a big stride, only by improving the talents cultivation, the country can compete with other counties, and stay in an invincible position in the global competition in the new century. The talent strategy determine the future and destiny of the country, and it is becoming as an important subject we should pay more and more attention[2].

In order to solve these problems, we must rely on the education mechanism, and the science and technology mechanism and reform mechanism should be taken into consideration at the same time[3]. Therefore, we must deepen the education mechanism system reform, and the collaboration of the multiple mechanisms should be developed. The barriers of technological progress and innovation need to be eliminated in further, technology system and economic reform is promoted, and the technological progress and technology innovation are obtained. The dominant position of enterprises, universities and research institutes are strengthened. The technological resources of the whole society are integrated effectively[4]. The combination of economic and technology is promoted closely. The basic architecture that the enterprise is the body, and the market is the guidance is established, and the enterprises, universities and research institutes are combined for developing the industry study and research, the combination of technology and economy are promoted effectively, and accelerate and improve the industrialization of scientific and technological achievements. The development of science and technology competitiveness is promoted. The remarkable social and economic benefits are obtained. The achievement has been widely agreed by the whole society[5].

\section{How to cultivate the practical ability of English talent with integration of industry study and research in college}

Combination and integration of industry study and research refers to the cooperation sectors and higher vocational colleges to follow the principle of equality and mutual benefit in terms of educating people together. The education resources of education higher vocational colleges, industry, enterprises, government departments, and training institutions are taken in advantage, the different educational environments and resource environments are used. The application-oriented talents are cultivated, and the application-oriented talents can meet the requirements of industry and companies. The main purpose of education model is shown as this purpose. The Ministry of Education, "a number of opinions on the overall improvement of teaching quality of higher vocational education" to teach high (2006) document NO. 16 states: adhere to the service is the purpose, the employment is orientation, and the road of combining of industry, study and research is taken. In the Higher Vocational Education, the business English talents are cultivated, and the guidance as before should be adhered, a new business English talents cultivation mode is proposed. The research of the new English talents cultivation mode based on industry, study and research can be available from the following aspects:

\section{A. Social enterprise industry, industry sector participate in the training plan development of English talents}

The training plan is the key link of Business English professional adapts to the society needs in initiative, the Steering Committee of Business English is formed, and training objectives, specifications and teaching plans are demonstrated. The representative foreign trade enterprises and companies are selected, and the experts in related units are combined as a committee, the professional courses development is taken, and ability and quality of personnel training program is 
developed, the structure of the course and scheme is modified, according to the course table, the knowledge, ability and quality of the students are determined in accordance with the structure of the course, and the related company's experts study and determine the course scheme.

According to the Business English orientation in Higher Vocational, it should be to meet the market need for business English talent, and it is a precondition. Students should be competent in international business professional positions, it is shown as the goal in education, to improve the ability of students, and the foreign trade professional position is the starting point. From the point of view of professional attributes, it has the characteristics of English teaching first of all, the $s$ basic skills ability such as listening, speaking, reading, writing and translation are necessary.

Secondly, the new mode has the characteristics of vocational ESP English teaching as the purposes context, the purposes is that cultivate the students use English proficiency to conduct business activities in future. Therefore, Vocational Business English training talents both have the solid foundation in English and business-related knowledge and skills. They should have comprehensive professional competency. In view of the above characteristics, the training objectives of Business English training objectives must be distinguished from ordinary English higher education. Vocational Business English training objectives are shown as: to cultivate socialist economic construction, moral, intellectual, physical, and aesthetic development, they should have a solid basic knowledge of the English language and the basic theory of international business engaged in professional positions necessary legal, policy and operational skills, competent foreign trade, foreign business management and services, marketing and other positions advanced skills, and they are application talents.

\section{B. Make full use of educational resources of foreign companies and other units}

The tangible assets and talents of foreign enterprises and units are valuable educational resources which is available in the community of Business English teaching, in the cooperation of industry study and research, foreign enterprises provide students with internships, training conditions, arrange for students to work in the front line, and provide a practical skills training base with practice teaching out of campus, the difficulties in teaching professional practice is solved. The practice teaching of Vocational Business English shows as experiment, training, practice, etc. and they are mainly divided into 3 aspects such as classroom practice, campus practice, and out campus practice. Classroom practice is mainly through classroom teaching methods, and increase the proportion of practice, and the theory is improved. In the campus practice, the language skills training and business skills training are developed, the related ability is improved. The conditions of language laboratory and business skills training center are taken in advantage. Various forms of training projects are organized, and for a particular skill, specific skills training are taken with one to two weeks per semester. The specific skills contain document production, import business talks, etc. The outdoor campus practice takes organization of international fair and cognitive training etc. The winter vacation and summer vacation are used for teaching practice, and the comprehensive training is developed at front line for foreign posts in the sixth semester.

In order to effectively carry out the practical aspects of teaching, establish a sound internal and external training base is very important. Business English training base includes multifunctional business English language laboratory and simulation laboratory. Language laboratory is used to train the basic ability as in listening, speaking, reading, writing, language translation, etc. Business English training simulation laboratory is mainly used to train the comprehensive business capabilities of students. On the basis of investigation of foreign trade enterprises and companies, the business English simulation laboratory is established, all the necessary training project software are equipped, create interactive teaching and learning environment. The simulation scene of mutual teacher-student interaction and foreign trade teaching and learning is created. In the simulation scene, the students can practice the English repeatedly, the natural and realistic foreign scene is formed, and the natural and realistic behavior and occupation ability required in business activities are formed. The professional ability is developed, and the social ability and personality development are made a great progress. In the training base out of the campus, it is the extension of practice teaching, and also is an important part of higher vocational practice teaching system. It is localized in foreign enterprises and companies mainly, the training and working environment is the real business environment, and the implementation of the standard are occupation standard. All 
kinds of content and project training are similar to the future occupation and work. For the first practice in the true environment, it should cultivate students' ability to solve business problems, and make students pass the occupation standard training. To complete the listening, speaking, reading, writing, translation, and business operations, the ability is improved. The objective of occupation moral quality and professional skill training is completed.

\section{Strengthen the construction of teachers on the quality of double quality}

For the construction of double division of business English Specialty in Higher Vocational Education, and "double quality" teachers should be cultivated, the high-quality vocational business English professional leader is cultivated. The selection of teacher with both teaching and scientific research ability is difficult but necessary, the teacher which has practical business operation ability and research ability is selected as the professional leader, with the leadership, and the professional construction is taken. The teaching pattern of the professional is explored. The professional and talents cultivation mechanism can obtain long-term sustainable development. With the training and cultivation of double quality teacher, the conditions is created, and training and test should be taken for testing the Business English professional post qualification, the qualification certificate is obtained. The school enterprise cooperation is carried out through great efforts, the teachers are selected to foreign enterprises and institutions engaged in part-time or post duty. The teachers can learn the latest technology and management norms. The latest achievements in the field of industry are introduced into the classroom.

The teachers also can participate in foreign trade enterprises and units of foreign business as foreign trade business translation and take the interpretation work. The traditional ideas should be broken out, and the practical experience is introduced directly from society, the business English teachers are enriched in higher education. Furthermore, to broaden the channels for people, the technical personnel are introduced in the classroom, and optimize the complementary structure. Then the structure of teaching staff is optimized. The overall structure of teachers is improved.

\section{Conclusion}

Integration of the industry study and research has important strategic status and significance in the process of social and economic development, and it has become the consensus of the world. In this paper, the theory of integration of the industry study and research is proposed. In order to promote the social and economic development, realize the organic unity of education, the science and technology, economy are taken as the main line. English talents cultivation mechanism is researched, and the better integration of collaborations is achieved. The new practical ability mode is proposed based on industry, study and research theory. A new integration path for improving the practical ability of English talent is explored, and the comprehensive national strength is enhanced as result.

\section{References}

[1] GUO Qiu-xia, DENG Xiang-ming, OU Yang-jiang. Evaluation of Value Chain Risks Based on BP Artificial Neural Network[J]. Logistics Technology. 2011; 30(7): 120-122.

[2] FANG Lu. Application of the Internet of Things Technology in the Museum Service[J]. Bulletin of Science and Technolog, 2013,3(28):166-168.

[3] Wang Ning, Li Gang. The Research on Online Exhibits Digitizing of Digital Museum[J]. Bulletin of Science and Technology, 2013, 29(2): 178-180.

[4] DENG Jing-sheng. The new view about reform of the method of pre-service teacher education practice under the background of new curriculum[J]. CAREER HORIZON, 2012, 8(9): 81-83.

[5] Chen Chaowen. Discussions on the Reform of Tanching Practice for Computer Science Majors[J]. Journal of Nanning Teachers College, 2005, 22(3):75-77. 